\title{
Single oral dose cure of lethal $P$. yoelii with a new iron chelator in human clinical trials for iron overload
}

\author{
Abhai Tripathi ${ }^{1}$, Hugh Rienhoff ${ }^{2}$, David Sullivan ${ }^{*}$ \\ From Parasite to Prevention: Advances in the understanding of malaria \\ Edinburgh, UK. 20-22 October 2010
}

\section{Background}

Iron chelators for the treatment of malaria have proven therapeutic activity in vitro and in vivo in both humans and mice, but their clinical use has been limited by the unsuitable adsorption and pharmacokinetic properties of the few available chelators. FBS0701 is an oral iron chelator currently in Phase 2 human studies for the treatment of transfusional iron overload. The drug has very favorable absorption and PK properties allowing for once-daily use to deplete circulating free iron. Once-daily administration of FBS0701 in humans at well tolerated doses can achieve plasma concentrations in the high $\mu \mathrm{M}$ range.

\section{Materials and methods}

P. falciparum drug inhibition was performed with Sybrgreen drug inhibition assays. Murine malaria was initiated by intraperitoneal inoculum of Balb/c mice followed for 30 days.

\section{Results}

FBS0701 has potent $\mathrm{IC}_{50}$ of $5 \mu \mathrm{M}$ in contrast to the $\mathrm{IC}_{50}$ for deferiprone and deferoxamine at 15 and $30 \mu \mathrm{M}$ respectively. The FBS0701 iron chelator was not antagonistic to the quinoloines or artemisinin in P. falciparum in vitro tests. In the P. berghei Thompson suppression

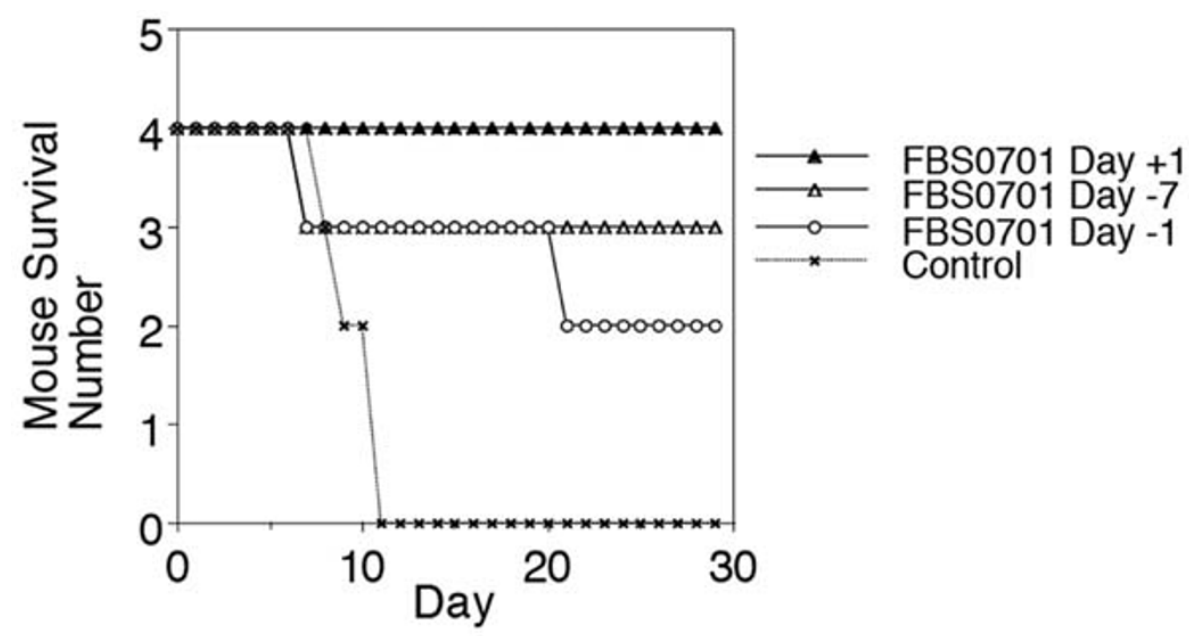

Figure 1 Four mice were inoculated with 10 million lethal P.yoelii parasites. The survival curve shows complete protection with Day +1 dosing and significant protection in animals pre-treated Day -7 and Day -1.

${ }^{1}$ The Malaria Research Institute, W. Harry Feinstone Department of Molecular Microbiology and Immunology, The Johns Hopkins Bloomberg School of Public Health, Baltimore, MD, USA

Full list of author information is available at the end of the article

(c) 2010 Tripathi et al; licensee BioMed Central Ltd. This is an open access article distributed under the terms of the Creative Commons 
test, $100 \mathrm{mg} / \mathrm{kg}$ reduced parasitemia at day three and prolonged survival, but did not cure mice. The number of daily doses - one, three or seven - did not significantly alter outcome in $P$. berghei infection. We then pre-treated mice with a single oral dose of $100 \mathrm{mg} / \mathrm{kg}$ of FBS0701 seven days or one day before infection with lethal $P$. yoelii 17XL. We also treated with a single dose one day after yoelii infection. All mice treated with a single dose one day following infection survived to 30 days in Figure 1. All untreated mice died by day 11. All FBS0701-treated mice had reduced parasitemia on day three. On day 16, the surviving FBS0701-treated mice had a significant reticulocytosis with more than $70 \%$ reticulocytes. Only 10 to $20 \%$ of mature erythrocytes were infected on day 16 in contrast to $40-60 \%$ of reticulocytes. By Day 23 post-infection, reticulocytosis and parasitemia had resolved.

\section{Conclusion}

FBS0701 demonstrates a single oral dose cure of the lethal $P$. yoelii model. Significantly, this effect persists after the chelator has cleared from plasma. FBS0701 may find clinically utility as monotherapy, a malarial prophylactic or, more likely, in combination with other antimalarials.

\section{Author details}

${ }^{1}$ The Malaria Research Institute, W. Harry Feinstone Department of Molecular Microbiology and Immunology,The Johns Hopkins Bloomberg School of Public Health, Baltimore, MD, USA. ${ }^{2}$ FerroKin BioSciences, Inc. San Carlos, CA, USA.

Published: 20 October 2010

doi:10.1186/1475-2875-9-S2-P54

Cite this article as: Tripathi et al: Single oral dose cure of lethal $P$. yoelii with a new iron chelator in human clinical trials for iron overload. Malaria Journal 2010 9(Suppl 2):P54.
Submit your next manuscript to BioMed Central and take full advantage of:

- Convenient online submission

- Thorough peer review

- No space constraints or color figure charges

- Immediate publication on acceptance

- Inclusion in PubMed, CAS, Scopus and Google Scholar

- Research which is freely available for redistribution

Submit your manuscript at www.biomedcentral.com/submit 